\title{
PENGARUH MISFIT KETIDAKPASTIAN BISNIS YANG DIPERSEPSIKAN DENGAN LEVERS OF CONTROL TERHADAP KINERJA PERUSAHAAN
}

\author{
I Made Pradana Adiputra ${ }^{1}$ \\ Universitas Pendidikan Ganesha \\ adiputra@undiksha.ac.id \\ Hilda Rossieta ${ }^{3}$ \\ Fakultas Ekonomi dan Bisnis \\ Universitas Indonesia \\ enjum9@yahoo.co.uk
}

\author{
Lindawati Gani² \\ Fakultas Ekonomi dan Bisnis \\ Universitas Indonesia \\ lgani88@gmail.com
}

\author{
Ancella A. Hermawan ${ }^{4}$ \\ Fakultas Ekonomi dan Bisnis \\ Universitas Indonesia \\ ancella_hermawan@yahoo.com
}

\begin{abstract}
ABSTRAK
Penelitian ini bertujuan untuk memberikan bukti empiris tentang pengaruh misfit ketidakpastian bisnis yang dipersepsikan dengan sistem pengendalian manajemen (levers of control) terhadap kinerja keuangan dan kinerja non-keuangan hotel di Bali. Sampel penelitian adalah hotel klasifikasi bintang 1 sampai 5. Responden adalah manajer yang ditentukan melalui purposive sampling. 181 manajer berpartisipasi dengan mengembalikan kuesioner. Pengujian hipotesis penelitian menggunakan analisis regresi misfit residual dengan program SPSS. Hasil penelitian menunjukkan bahwa pengaruh misfit ketidakpastian bisnis yang dipersepsikan dengan sistem pengendalian manajemen memiliki pengaruh negatif terhadap kinerja keuangan dan kinerja non-keuangan. Analisis sensitivitas menggunakan pengukuran lain sistem pengendalian manajemen konsisten dengan hasil utama.
\end{abstract}

Kata Kunci : Sistem pengendalian manajemen; ketidakpastian bisnis yang dipersepsikan; kinerja perusahaan

\begin{abstract}
This study aims to provide empirical evidence about the effect of misfit business uncertainty perceived by management control systems (levers of control) has a negative influence on financial performance and nonfinancial performance of hotels in Bali. The research sample is a 1 to 5 star classification hotel. Respondents are managers who are determined through purposive sampling. 181 managers participated by returning the questionnaire. Testing the research hypothesis using regression analysis of residual misfit with the SPSS program. The results showed that the effect of business uncertainty misfit perceived by management control systems had a negative influence on financial performance and nonfinancial performance. Sensitivity analysis uses other measurement management control systems consistent with the main results.
\end{abstract}

Keywords: Management control system; perceived business uncertainty; firm performance

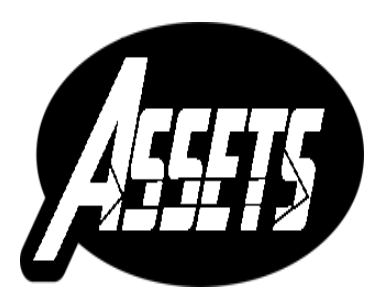

ASSETS

Jurnal Akuntansi dan Pendidikan

Vol. 8 No. 2

Hlmn. 117-125

Madiun, Oktober 2019

p-ISSN: 2302-6251

e-ISSN: 2477-4995

Artikel masuk:

10 Juni 2019

Tanggal diterima: 4 Oktober 2019 


\section{PENDAHULUAN}

Dampak pesatnya pergerakan industri, membuat para pelaku bisnis di Indonesia harus siap menerima revolusi industri 4.0 (Aditya, 2017). Kondisi tersebut berkaitan dengan teknologi yang mengubah cara hidup, bekerja, dan relasi organisasi dalam berhubungan satu sama lain (Cahyono, 2018). Implikasinya pengelolaan bisnis tidak lagi berpusat pada kepemilikan individual namun pembagian peran atau kolaborasi atau gotong royong (Kasali, 2017).

Kesiapan pihak manajemen perusahaan memerlukan perencanaan dan pengendalian seluruh komponen atau tingkatan dalam perusahaan untuk bersamasama mencapai tujuan perusahaan. Oleh karena itu sistem pengendalian manajemen (SPM) merupakan salah satu aspek penting dalam perilaku organisasi dan diterapkan secara seimbang antar levers (Kruis, Spekle, \& Widener, 2016). Martyn, Sweeney, \& Curtis (2016) menyatakan kerangka kerja SPM secara komprehensif menunjukkan representasi atas aspek nilai inti, perilaku, pengawasan dan umpan balik. Kerangka kerja tersebut disebut sebagai levers of control (LoC) yang dikemukakan oleh Simons (2014) dan banyak digunakan dalam beberapa penelitian pada bidang pengendalian manajemen selama lebih dari dua dekade. Kerangka LoC memotivasi dan memberikan informasi bagi karyawan untuk mengambil tindakan yang lebih terarah. Peran SPM berdampak terhadap efektivitas pengendalian organisasi yang terdapat pada komponen SPM meliputi beliefs control yaitu nilai dasar, tujuan, dan arahan bagi organisasi, boundary control berperan dalam mengkomunikasikan risiko yang harus dihindari, diagnostic control berfungsi memantau hasil organisasi dan memperbaiki penyimpangan dari standar kinerja serta interactive control dalam mengkomunikasikan informasi antara atasan dan bawahan (Simons, 2014). LoC menjadi dasar bagi individu dalam organisasi untuk mengendalikan perilakunya agar bertindak sesuai dengan tujuan organisasi melalui peran masing-masing levers. Kinerja organisasi akan lebih mudah dicapai ketika setiap levers berjalan sesuai fungsinya.

LoC merupakan alat manajemen strategis dan kerangka teoritis untuk memahami hubungannya dengan konteks pengendalian dalam organisasi. Simons (2014) berpendapat bahwa suksesnya perusahaan dalam menerapkan strategi harus dilakukan oleh manajemen dengan memahami empat variabel strategis utama, yaitu: nilai-nilai inti, ketidakpastian, risiko yang harus dihindari dan variabel kinerja yang tertuang pada masing-masing LoC. Strategi, ketidakpastian, risiko, kinerja dengan saling terkait dan mendukung satu dengan lainnya. Widener (2007) memfokuskan pada aspek ketidakpastian strategis yang dihadapi perusahaan yang mendominasi pengaruhnya terhadap LoC sehingga akan diketahui dampaknya terhadap kinerja perusahaan. Sementara itu, Fauzi, Hussain, \& Mahoney (2009) memandang bahwa ketidakpastian lingkungan bersama faktor kontinjen lainnya memiliki pengaruh terhadap kinerja perusahaan.

Penelitian ini mengembangkan dan mengadopsi ketidakpastian bisnis yang dipersepsikan (perceived business uncertainty) sebagai variabel kontinjensi. Alasannya pertama, ketidakpastian bisnis yang dipersepsikan top manajer merupakan faktor kontinjensi yang paling penting mempengaruhi pengambilan keputusan manajerial perusahaan (Subramaniam, Collier, Phang, \& Burke, 2011) Selain itu, faktor ini masih terbatas digunakan pada penelitian tentang SPM dan kinerja perusahaan.

Spesifikasi arti bisnis dalam konteks ketidakpastian. Pertama, di dalamnya terdapat indikator tentang aspek risiko yang dihadapi perusahaan yang belum dijadikan sebagai indikator faktor ketidakpastian pada penelitian SPM sebelumnya. Kedua, ketidakpastian bisnis memiliki lingkup lebih besar yang umumnya terkait dengan ketidakpastian dalam tindakan pemangku kepentingan utama organisasi 
seperti pelanggan, pemasok, pesaing, dan kelompok regulator (Subramaniam et al., 2011). Ketiga, banyak penelitian terdahulu yang lebih menganalisis strategi sebagai faktor kontinjen atau dampak ketidakpastian terhadap penentuan strategi. Esensi dasar pendekatan kontinjensi mengatakan bahwa organisasi harus beradaptasi dengan faktor kontinjensinya seperti lingkungan, ukuran organisasi dan strategi bisnis yang dijalankan dengan baik (Gerdin \& Greve, 2008).

Penelitian ini menggunakan pendekatan misfit seperti yang dilakukan oleh Gani \& Jermias (2012) yang menggunakan pendekatan misfit antara sistem pengendalian manajemen dan strategi berpengaruh terhadap kinerja perusahaan pada bank di Indonesia. Misfit menunjukkan deviasi antara variabel sistem pengendalian manajemen dan strategi berimplikasi negatif terhadap kinerja (Gani \& Jermias, 2012). Dengan demikian konsep misfit berdasarkan besaran ketidaksesuaian (misfit) melalui konsep residual (Riyanto, 2001). Implementasi konsep misfit tersebut dalam penelitian ini adalah ketika ketidaksesuaian ketidakpastian bisnis yang dipersepsikan semakin tinggi (rendah) dengan mekanisme levers of control akan menyebabkan kinerja persuahaan akan semakin rendah (tinggi).

Berdasarkan pemikiran tersebut maka kontribusi penelitian ini adalah untuk pengembangan literatur secara konseptual bahwa ketidakpastian bisnis memiliki ruang lingkup yang lebih luas dibandingkan faktor ketidakpastian lingkungan yang selama ini lebih banyak digunakan. Hal tersebut berdasarkan bahwa terdapat komponen ketidakpastian lingkungan dan risiko dalam ketidakpastian bisnis. Penelitian ini dilakukan pada industri jasa yaitu hotel karena industri jasa tersebut sangat bergantung pada lingkungan bisnis yang penuh dengan kondisi ketidakpastian yang harus diantisipasi dengan proses pengendalian manajemen.

Bisnis industri pariwisata merupakan salah industri jasa yang rentan terhadap ketidakpastian bisnis. Aspek kepercayaan terhadap pelayanan jasa tersebut memerlukan dukungan sumber daya manusia dan teknologi. Kementerian Pariwisata melalui program Pariwisata 4.0 membawa perubahan yang signifikan dalam penyelenggaraan kepariwisataan. Untuk itu dibutuhkan kehadiran unsur kunci pendukung seperti sumber daya manusia (SDM) atau humanware, hubungan kerja/kolaborasi atau orgaware dan berbagai informasi deskriptif maupun preskriptif yang membuat teknologi tersebut dapat bekerja atau infoware (Selviany, 2018).

Penelitian ini akan menguji tingkat ketidaksesuaian (misfit) ketidakpastian bisnis yang dipersepsikan dengan sistem pengendalian manajemen (levers of control) berpengaruh negatif erhadap kinerja perusahaan (hotel). Indikasi pengaruh negatif menjadi faktor yang dihasilkan atas analisis misfit (Riyanto, 2001). Tujuan penelitian ini adalah memberikan bukti empiris tentang tingkat ketidaksesuaian (misfit) ketidakpastian bisnis dengan sistem pengendalian manajemen (levers of control) akan berpengaruh negatif terhadap kinerja perusahaan.

\section{METODE PENELITIAN}

Populasi penelitian adalah seluruh hotel berlokasi di Bali. Penentuan sampel penelitian menggunakan purposive sampling yaitu hotel klasifikasi bintang 1 sampai dengan 5 yang terdaftar pada database Dinas Pariwisata Propinsi Bali dan Perhimpunan Hotel dan Restauran (PHRI) Bali Tahun 2018 sebanyak 227 hotel. Responden penelitian adalah senior manajer dengan minimal masa kerja 1 (satu) tahun dan memiliki informasi lengkap dan menyeluruh tentang kebijakan dan operasional perusahaan. Bentuk penelitian ini adalah kuantitatif dengan metode pengumpulan data menggunakan data primer menggunakan angket (kuesioner) dan data sekunder yang diperoleh dari annual report perusahaan dan PHRI. 
Pengukuran variabel sistem pengendalian manajemen dalam kerangka levers of control menggunakan 17 item pertanyaan yang diadopsi dari Widener (2007), terdiri dari masing-masing 4 (empat) item untuk mengukur intensitas penggunaan beliefs, boundary dan diagnostic control. 5 (lima) item pertanyaan digunakan untuk mengukur intensitas penggunaan interactive control. Integrasi atau penggunaan bersama keempat levers of control tersebut menunjukkan pelaksanaan sistem pengendalian manajemen perusahaan. Pengukuran menggunakan skala likert 1-5. Semakin tinggi skor dari seluruh item pertanyaan menunjukkan semakin tinggi intensitas penggunaan levers of control. Variabel ketidakpastian bisnis yang dipersepsikan (KBD) merupakan ketidakpastian bisnis yang dipersepsikan dinilai menggunakan empat item diadopsi dari Subramaniam et al. (2011) yang berkaitan dengan tingkat ketidakpastian secara keseluruhan di sektor industri, tingkat persaingan, tingkat risiko yang dihadapi oleh organisasi serta yang dihadapi oleh sektor industri perusahaan. Pengukuran menggunakan skala likert 1-5. Semakin tinggi skor dari seluruh item pertanyaan menunjukkan semakin tinggi ketidakpastian bisnis yang dipersepsikan. Variabel kinerja perusahaan didefinisikan sebagai pencapaian tujuan yang telah ditetapkan oleh perusahaan baik dari aspek keuangan maupun non keuangan. Kinerja perusahaan diukur dengan menggunakan 10 (sepuluh) item pertanyaan yang diadopsi dari Gani \& Jermias (2012) yang dilihat dari keuangan dan non keuangan. Pengukuran menggunakan skala likert 1-5. Semakin tinggi skor dari seluruh item pertanyaan menunjukkan semakin tingginya standar pencapaian kinerja keuangan dan non keuangan oleh perusahaan. Variabel kontrol meliputi total aset yang dimiliki hotel berbintang yang disajikan dalam annual report tahun 2018 dan klasifikasi hotel berbintang dengan kriteria: $5=$ hotel bintang $5 ; 4=$ hotel bintang $4 ; 3=$ hotel bintang $3 ; 2$ hotel bintang 2 dan 1 = hotel bintang 1 .

Analisis data penelitian menggunakan metode statistik regresi dengan pendekatan misfit dengan nilai residual yang diadopsi dari Riyanto (2001). Formulasi pengujian hipotesis menggunakan analisis regresi yaitu:

Ketidakpastian Bisnis Yang Dipersepsikan $(\mathrm{KBD})=\alpha 0+\beta 1$ Beliefs $+\beta 2$

Boundary $+\beta 3$ Diagnostic $+\beta 4$ Interactive $+\varepsilon \ldots$ persamaan (1)

Sementara itu, pengujian misfit ketidakpastian bisnis yang dipersepsikan dan SPM terhadap kinerja keuangan dan non keuangan dengan variabel kontrol aset dan klasifikasi bintang, yaitu:

Kinerja Keuangan $=\lambda_{0}+\lambda_{1}\left|\varepsilon_{i}\right|+\lambda_{2}$ Asset $+\lambda_{3}$ Klasifikasi Bintang $+v \ldots$

persamaan (2)

Kinerja Non Keuangan $=\lambda_{0}+\lambda 1|\varepsilon \mathbf{i}|+\lambda_{2}$ Asset $+\lambda_{3}$ Klasifikasi Bintang +

v ... persamaan (3)

Pengujian Statistik dilakukan melalui tahapan uji kualitas data yaitu uji reliabilitas dan validitas. Dilakukan pula analisis sensitivitas dengan menggunakan pengukuran SPM mengadopsi dari penelitian Gani \& Jermias (2012) dengan 20 item pertanyaan yang terbagi ke dalam evaluasi kinerja, komunikasi, resolusi konflik dan komitmen karyawan.

\section{HASIL PENELITIAN DAN PEMBAHASAN}

Data berdasarkan jawaban 181 orang general manager dan setingkat manajer berpartisipasi mengisi kuesioner. Profil responden berdasarkan jabatan meliputi general manager sebanyak $17,21 \%$, manajer dan setingkat manajer sebanyak $82,88 \%$. Berdasarkan jenis kelamin yaitu pria sebanyak $70,17 \%$ dan wanita sebanyak $29,83 \%$. Berdasarkan lama menjabat yaitu lebih dari 10 tahun sebanyak $10,50 \%$ dan kurang dari 10 tahun sebanyak $89,50 \%$. 
Tabel 1. Statistik Deskriptif

\begin{tabular}{lcccc}
\hline \multicolumn{1}{c}{ Variabel } & Mean & Maks & Min & SD \\
\hline SPM & 78.71 & 84 & 68 & 6.62 \\
Ketidakpastian Bisnis & 18,73 & 20 & 15 & 2,23 \\
Kinerja Keuangan & 23.17 & 25 & 22 & 2.91 \\
Kinerja Non Keuangan & 24.35 & 25 & 24 & 2.87 \\
Data Sekunder: & & & & \\
Total Aset & 1.4 trilyun & 39.6 trilyun & 22 trilyun & 6.7 tilyun \\
Klas. Bintang & 2.96 & 5 & 1 & 1.33 \\
\hline
\end{tabular}

Tabel 1 menunjukkan bahwa responden menunjukkan kondisi SPM melalui levers of control pada tingkat yang baik, ketidakpastian bisnis yang dipersepsikan yang tinggi, kinerja keuangan dan non keuangan yang tinggi standar pencapaiannya, total asset rata-rata 1,4 trilyun dan hotel bintang 3 yang lebih banyak berpartisipasi dalam penelitian.

Tabel 2. Regresi Pengaruh Sistem Pengendalian Manajemen terhadap Ketidakpastian Bisnis Yang Dipersepsikan (KBD)

\begin{tabular}{|c|c|}
\hline Variabel & Koefisien KBD (signifikansi) \\
\hline Intercept & $1,050^{* *}$ \\
\hline Beliefs & $0,954^{* *}$ \\
\hline Boundary & $1,072^{* *}$ \\
\hline Diagnostic & $0,955^{* *}$ \\
\hline Interactive & $0,042^{* *}$ \\
\hline Adjusted $R^{2}$ & 0,796 \\
\hline Jumlah daya yang diuji & 181 \\
\hline
\end{tabular}

Berdasarkan tabel 2. menunjukkan bahwa semua indikator SPM berpengaruh positif terhadap KBD pada hotel berbintang di Bali. Hal tersebut mengindikasikan bahwa SPM memiliki pengaruh kuat untuk mengantisipasi KBD pada industri hotel dilihat dari indikator SPM.

Selanjutnya dilakukan pengujian regresi misfit KBD melalui absolut residual yang diperoleh dari persamaan regresi awal yang akan diregresikan dengan variabel dependen yaitu kinerja keuangan dan kinerja non keuangan serta variabel kontrol aset dan klasifikasi bintang pada hotel pada tabel 3 dan 4.

Berdasarkan tabel 3, variabel misfit bertanda negatif dan signifikan, artinya adanya misfit KBD dengan SPM berpengaruh negatif terhadap kinerja keuangan pada signifikansi 0.05. Hal tersebut menunjukkan bahwa KBD pada industri hotel berada pada tingkat kesesuaian (misfit yang rendah) dengan pelaksanaan SPM perusahaan sehingga kesesuaian keduanya akan berpengaruh negatif pada kinerja keuangan perusahaan. KBD yang dihadapi hotel dalam menjalankan operasionalnya dapat diantisipasi dengan baik sehingga berdampak terhadap desain SPM yang telah dibuat oleh hotel. Desain SPM tersebut meliputi upaya hotel dalam meningkatkan efektivitasnya terhadap komponen belief, boundary, diagnostic dan interactive control yang dapat diterima seluruh individu dalam tingkatan manajemen hotel. Dengan demikian adanya antisipasi KBD akan menyebabkan terciptanya keselarasan antara kepentingan seluruh individu dan pihak hotel dalam menghasilkan kinerja keuangan hotel. 
Tabel 3. Regresi Misfit

\begin{tabular}{lr}
\hline \multicolumn{1}{c}{ Variabel } & Koefisien KBD (signifikansi) \\
\hline Intercept & $9,797^{* *}$ \\
Misfit & $-0,357^{* *}$ \\
Aset & $5,268^{* *}$ \\
Bintang & $-0,038$ \\
Adjusted $R^{2}$ & 0,19 \\
Jumlah data yang diuji & 181 \\
\hline
\end{tabular}

Variabel aset dalam pengujian juga menunjukkan hasil yang signifikan bahwa aset berpengaruh pada KBD dan SPM pada industri hotel di Bali sebagai modal utama dalam aktivitas bisnis jasa khususnya hotel. Akan tetapi berdasarkan klasifikasi bintang pada pengujian menunjukkan hasil tidak signifikan, artinya klasifikasi bintang belum sepenuhnya menjadi faktor yang dipertimbangkan dalam mempengaruhi antara KBD dengan SPM pada industri hotel. Dalam hal ini bukan tentang harus mencapai tingkat klasifkasi bintang hotel akan tetapi hotel cenderung berfokus bagaimana mengantisipasi berbagai dinamika dan kompetisi aktivitas bisnis yang terjadi untuk kelangsungan perusahaan dan kepercayaan tamu hotel melalui SPM yang efektif melalui pelayanan hotel terbaik yang dapat diberikan. Hasil penelitian sejalan dengan Fauzi et al. (2009) serta Gani dan Jermias (2012) meskipun dengan faktor kontinjen baru yang berbeda yaitu ketidakpastian bisnis yang dipersepsikan.

Tabel 4. Regresi Misfit

\begin{tabular}{lr}
\hline \multicolumn{1}{c}{ Variabel } & Koefisien KBD (signifikansi) \\
\hline Intercept & $9,601^{* *}$ \\
Misfit & $-0,095^{* *}$ \\
Aset & $1,513^{* *}$ \\
Bintang & $-0,123$ \\
Adjusted $R^{2}$ & 0,13 \\
Jumlah data yang diuji & 181 \\
\hline
\end{tabular}

Berdasarkan tabel 4 diatas menunjukkan bahwa variabel misfit adalah bertanda negatif dan signifikan, artinya adanya misfit KBD dengan SPM berpengaruh negatif terhadap kinerja non-keuangan pada signifikansi 0.05. Sejalan dengan pengaruhnya terhadap kinerja keuangan, KBD pada industri hotel terjadi kesesuaian (misfit yang rendah) dengan pelaksanaan SPM perusahaan sehingga kesesuaian keduanya akan berpengaruh negatif pada kinerja non-keuangan perusahaan.

Misfit yang rendah berarti terdapat kesesuaian yang tinggi antara KBD dengan SPM. Hal tersebut menunjukkan bahwa hotel dapat mengantisipasi terjadinya ketidakpastian bisnis yang dihadapi. Hal tersebut juga membuktikan bahwa SPM hotel telah dibuat dan dilaksanakan dengan baik oleh seluruh individu dalam perusahaan sehingga selaras dengan tujuan perusahaan dapat meningkatkan kinerja non keuangannya. Kinerja non keuangan disini berarti bahwa adanya kesesuaian KBD dan SPM akan berdampak pada orientasi hotel untuk menciptakan kepuasan tamu hotel dan pekerjanya sebagai indikator kinerja non keuangan,

Seperti pada kinerja keuangan sebelumnya bahwa variabel aset dalam pengujian juga menunjukkan hasil yang signifikan bahwa aset berpengaruh pada KBD dan SPM pada industri hotel di Bali. Aset menjadi faktor penting bagi hotel untuk mengupayakan mewujudkan tujuan perusahaan dari aspek kinerja non-keuangan yang berfokus pada karyawan dan tamu hotel. Berdasarkan klasifikasi bintang pada 
pengujian juga menunjukkan hasil tidak signifikan, artinya sejalan dengan alasan pada pembahasan KBD dengan SPM terhadap kinerja keuangan, klasifikasi bintang belum sepenuhnya menjadi faktor yang dipertimbangkan dalam mempengaruhi KBD dengan SPM pada perusahaan terhadap kinerja non-keuangan pada hotel. Hasil penelitian sejalan dengan Gani dan Jermias (2012) dengan faktor kontinjen yang berbeda pada penelitian ini.

Hasil penelitian diatas membuktikan bahwa faktor kontinjen sangat berperan penting dalam menentukan desain SPM hotel sehingga berdampak pada proses pertanggungjawaban manajer yang mewakili perusahaan terhadap prinsipal sebagai pemilik modal/investasi yang lebih baik sebagai konsekuensi prinsip agensi. Sementara itu hasil penelitian juga membuktikan bahwa peran faktor kontinjen memberikan manfaat pada bagaimana hotel menggunakan dan memanfaatkan sumber daya yang dimiliki untuk berproses dengan seluruh tingkatan manajemen dalam melakukan proses pengambilan keputusan sesuai dengan prinsip resource dependence theory.

Penelitian ini melakukan analisis sensitivitas untuk menguji apakah pengukuran variabel SPM menggunakan pengukuran yang lain akan menghasilkan temuan yang sama dalam model penelitian. Berdasarkan tabel 5, variabel misfit bertanda negatif dan signifikan, artinya adanya misfit KBD dengan SPM berpengaruh negatif terhadap kinerja keuangan pada signifikansi 0,05. Hal tersebut menunjukkan bahwa KBD pada industri hotel berada pada tingkat kesesuaian (misfit yang rendah) dengan pelaksanaan SPM perusahaan sehingga kesesuaian keduanya akan berpengaruh negatif pada kinerja keuangan perusahaan.

Berdasarkan tabel 6, variabel misfit bertanda negatif dan signifikan, artinya adanya misfit KBD dengan SPM berpengaruh negatif terhadap kinerja non keuangan pada signifikansi 0.05. Hal tersebut menunjukkan bahwa KBD pada industri hotel berada pada tingkat kesesuaian (misfit yang rendah) dengan pelaksanaan SPM perusahaan sehingga kesesuaian keduanya akan berpengaruh negartif pada kinerja non keuangan perusahaan.

Tabel 5. Analisis Sensitivitas Regresi Misfit (Kinerja Keuangan)

\begin{tabular}{lr}
\hline \multicolumn{1}{c}{ Variabel } & Koefisien KBD (signifikansi) \\
\hline Intercept & $10,147^{* *}$ \\
Misfit & $-0,557^{* *}$ \\
Aset & $5,476^{* *}$ \\
Bintang & $-0,068$ \\
Adjusted $R^{2}$ & 0,21 \\
Jumlah data yang diuji & 181 \\
\hline
\end{tabular}

Tabel 6. Analisis Sensitivitas Regresi Misfit (Kinerja Non Keuangan)

\begin{tabular}{lr}
\hline \multicolumn{1}{c}{ Variabel } & Koefisien KBD (signifikansi) \\
\hline Intercept & 10,272 \\
Misfit & $-0,125$ \\
Aset & 1,623 \\
Bintang & $-0,161$ \\
Adjusted $R^{2}$ & 0,15 \\
Jumlah data yang diuji & 181 \\
\hline
\end{tabular}




\section{SIMPULAN}

Hasil penelitian menunjukkan bahwa terdapat pengaruh misfit ketidakpastian bisnis yang dipersepsikan dengan SPM berpengaruh negatif terhadap kinerja keuangan dan kinerja non-keuangan pada industri hotel di Bali. Penggunaan variabel kontinjen ketidakpastian bisnis yang dipersepsikan merupakan kebaruan dalam penelitian yang membahas tentang SPM (levers of control) yang belum dilakukan pada penelitian sebelumnya dengan pendekatan misfit. Temuan menarik dari penelitian ini bahwa ketidakpastian bisnis yang dipersepsikan melalui faktor lingkungan dan risiko yang menjadi indikatornya memiliki kepentingan yang krusial dalam menentukan efektivitas SPM hotel. Tidak hanya melihat dari kondisi lingkungan eksternal yang terjadi akan tetapi melihat faktor risiko yang harus diantisipasi hotel sehingga berdampak terhadap kinerja hotel.

Implikasi penelitian ini bahwa ketidakpastian bisnis yang dipersepsikan meliputi faktor lingkungan, persaingan dan risiko memiliki peran penting untuk menentukan desain SPM sehingga berpengaruh terhadap kinerja keuangan dan non keuangan hotel. Desain SPM akan sangat ditentukan oleh kondisi lingkungan bisnis, tingkat persaingan bisnis dan munculnya risiko bisnis yang harus dihadapi sehingga akan berdampak terhadap kinerja perusahaan. Keterbatasan penelitian adalah faktor kontinjen ketidakpastian bisnis yang dipersepsikan merupakan faktor baru yang digunakan dalam penelitian SPM dan diadopsi sepenuhnya dari Subramaniam et al. (2011) yang masih perlu dikembangkan pengukurannya untuk mewakili aspek lingkungan, persaingan dan risiko perusahaan; industri jasa perhotelan memberikan konteks/hasil yang berbeda dibandingkan industri non jasa lainnya; penggunaan variabel kontrol dalam penelitian yang hanya menggunakan total aset dan klasifikasi bintang pada hotel akan memberikan hasil yang berbeda jika menggunakan variabel kontrol lainnya seperti: size dan rasio keuangan perusahaan dari annual report.

\section{DAFTAR PUSTAKA}

Aditya, R. (2017). Industri 4.0, Kolaborasi Digital dan Lini Produksi Industri. Diakses pada 15 Februari 2019, dari https:// beritagar.id/artikel/ berita/industri-40-kolaborasi-digital-dan-liniproduksi-industri.

Cahyono, E. (2018). Revolusi Industri 4.0 dan Transformasi Organisasi Pemerintah. Diakses pada 15 Februari 2019, dari https://setkab.go.id/revolusi- industri-4-0dan-transformasi-organisasi-pemerintah.

Fauzi, H., Hussain, M.M., dan Mahoney, L. (2009). Management Control Systems and Contextual Variables in the Hospitality Industry. Diunduh pada 28 Januari 2019 dari www.ssrn.com.

Gani, L., dan Jermias, J. (2012). The Effect of Strategy-Management Control System Misfits on Firm Performance. Accounting Perspective. Vol. 11. No. 3. 165-196.

Gerdin, J., dan Greve, J., (2008). The Appropriateness of Statistical Methods for Testing Contingency Hypotheses in Management Accounting Research. Accounting Organizations and Society, 33, 995-1009.

Kasali, R. (2017). Meluruskan Pemahaman Soal Disruption. Diunduh pada 15 Februari 2019, dari https://ekonomi.kompas.com/read/2017/05/05/073000626/meluruskan.pema haman.soal.disruption.

Kruis, A-M., Spekle, R.F., dan Widener, S.K. (2016). The Levers of Control Framework: An Exploratory Analysis of balance. Management Accounting Research, 32, 27 44 . 
Martyn, P., Sweeney, B., dan Curtis, E. (2016). Strategy and Control: 25 Years of Empirical Use of Simons' Levers of Control Framework. Journal of Accounting \& Organizational Change, Vol. 12 Issue: 3, 281-324.

Riyanto, L.S, B. (2001). An Examination of the Impact of the Fit between Strategic Uncertainty and Management Accounting Systems on Financial Performance. Jurnal Riset Akuntansi Indonesia, 1-28.

Selviany, D. (2018). Selain Revolusi Industri 4.0 Kemenpar Juga Dorong Pariwisata 4.0, Apa Itu?. Diunduh pada 15 Februari 2019, dari https://infonawacita.com/selainrevolusi-industri-4-0-kemenpar-juga-dorong-pariwisata-4-0-apa-itu.

Simons, R. (2014). Performance Measurement and Control Systems for Implementing Strategy. England: Pearson.

Subramaniam, N., Collier, P., Phang, M., \& Burke, G. (2011). The Effects of Perceived Business Uncertainty, External Consultants and Risk Management on Organisational Outcomes. Journal of Accounting \& Organizational Change, 7 (2), 132-157.

Widener, S.K. (2007). An Empirical Analysis of The Levers of Control Framework. Accounting, Organizations and Society, 32, 757-788. 